\title{
多変数離散モデルを用いた実験モード解析*
}

\author{
岡田養二*1, 高䚗昌*2 \\ 菘田健 一*1, 山中一雄*3
}

\section{Multivariable Discrete Model Identification of Vibrating Structure and Application to Experimental Modal Analysis}

\author{
Yohji OKADA, Takashi TAKAHI, \\ Kenichi MATSUDA, and Kazuo YAMANAKA
}

\begin{abstract}
Experimental modal analysis has been widely used to identify the modal parameters of structures. Mainly, it is based on analyzing the individual test signal either in the frequency domain or in the time domain. The main defect is the inaccuracy of the spatial mode shape caused by analyzing the individual measured signal. This paper introduces a new method of identifying the modal parameters from its decaying response. First, the multivariable discrete model is identified from the measured signal. Then the identified characteristic matrix is analyzed by an eigenvalue routine to get the vibrating poles and its associated modes. The proposed technique is applied to a plate structure and its accuracy is tested.
\end{abstract}

Key Words: Dynamics of Machinery, Measurement, Vibration, Discrete Model, Identification, Experimental Modal Analysis

\section{1. 緒言}

実験モード解析は，実験的に振動特性を把握する目 的や，動特性改善に役立てるために広く用いられてい る.これは測定された振動データから，固有振動数，減 衰率および振動モードを同定し，構造変更などに役立 てようとするものである(1) (3)。

同定手法としては，周波数領域による手法と(4)(5), 時間領域による方法がある(6) (8).どちらの方法にしろ， 振動波形のうちの成分の強い周波数について，各応答 波形のフィルタリング的抽出を行い, 固有振動数と減 衰率を求める。これを各振動波形に適用し，振動飞一 ドを求める手法が主である。著者らも時間領域で平均 化を行い,これに単点ごとの時系列解析を適用する方 法を提案した ${ }^{(9)}$.これらの方法での問題点は, 各振動 波形のわずかな計算誤差によって，一つのモードを近 接した二つのモードと誤認してしまうなど，空間的な 関連がないことである。したがって時間領域における フィルタ的な同定だけでなく，時間と空間の双方のフ

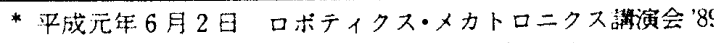
に拈いて講演，原稿受付 昭和 63 年 10 月 27 日。

*1 正員, 茨城大学 $工$ 学部 ( 316 日立市中成沢町 4-12-4).

*2学生員, 茨城大学大学院.

*1 茨城大学工学部.
}

イルタ特性を考えた同定法が，より好ましいと思え る。全体項を使うモ一ド解析も提案されている が(10)(11)，あまり普及していないようである。

一方で系の動特性を正確に同定したり，構造変更を 推定しやすいように，物理特性である質量 $\boldsymbol{m}$ ，ばね $\boldsymbol{k}$, 減衰 $c$ を直接同定しょうという研究も進んでい る(12) (14)。特性マトリックスが同定できれば，モード 特性のみならず系の動的性質がすべて判明する，しか しこの手法は，非線形な同定理論を使わなければなら す，計算効率の向上は難しい。

ここで提案する方法は，系を多変数の離散モデルに よって表し，離散系の特性マトリックスを同定する方 法である。離散系の場合は線形な同定方程式であり， 通常の最小二乗法が適用できる，次に同定された特性 マトリックスを固有値解析し, 特性根上り固有振動数 とモード減衰を求め，固有モードより振動モードを求 める方法である。

この方法は，基本的には構造物の減衰自由振動の， 同時多点計測を必要とする。そのためには，高洒なセ

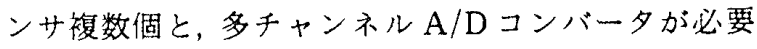
である。すくなくとも，著者らにこれを用意すること は不可能なので，1 点加振 1 点測定のハンマリング岕 答によって，多点同時計測と等価な測定とする。この 
場合，純粋なインパルス応答を必要とするため，FFT アナライザによって周波数領域で平均化し，その後逆 FFTによってインパルス応答に直すことが考光られ ろ. 著者ら法前報で(9)，時間領域の平均化てFFTの計 算誤差を受けることなく，精度のよいインパルス応答 が抽出できることを示した。本報ても，図Iに示す解 析システムでこの方法を使うので，簡単に平均化の考 え方を示す。

本方式の長所の一つは，測定点に 1 自由度を与える ことで，測定対象を多自由度でモデル化することにあ る、そのためランダム加振の AR 法 (Auto Regressive

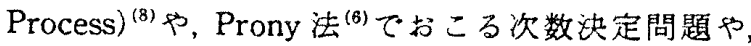
不安定根の発生は基本的にはない。唯一の久点は，測 定对象が集中定数系の場合，剩余項を考慮する合理的 で簡便な方法がないことである。

提案した手法を，まずアナログ計算機上にシミュレ ートした 5 自由度モデルに適用する。同定された固有 振動数, 減衰率, 振動モードを理論值と比較放るさら に実際の測定で起きやすい特定の点でのデータの倍率 が，1.5 倍になった場合のモード形への影響を検討す る。最後に宙吊り平板を実際にハンマリングし，モー ド同定を行う。これも有限要素法で解析した結果と比 較検討する。

\section{2. 同定アルゴリズム}

\section{$2 \cdot 1$ 離散運動方程式多自由度集中定数系近似}

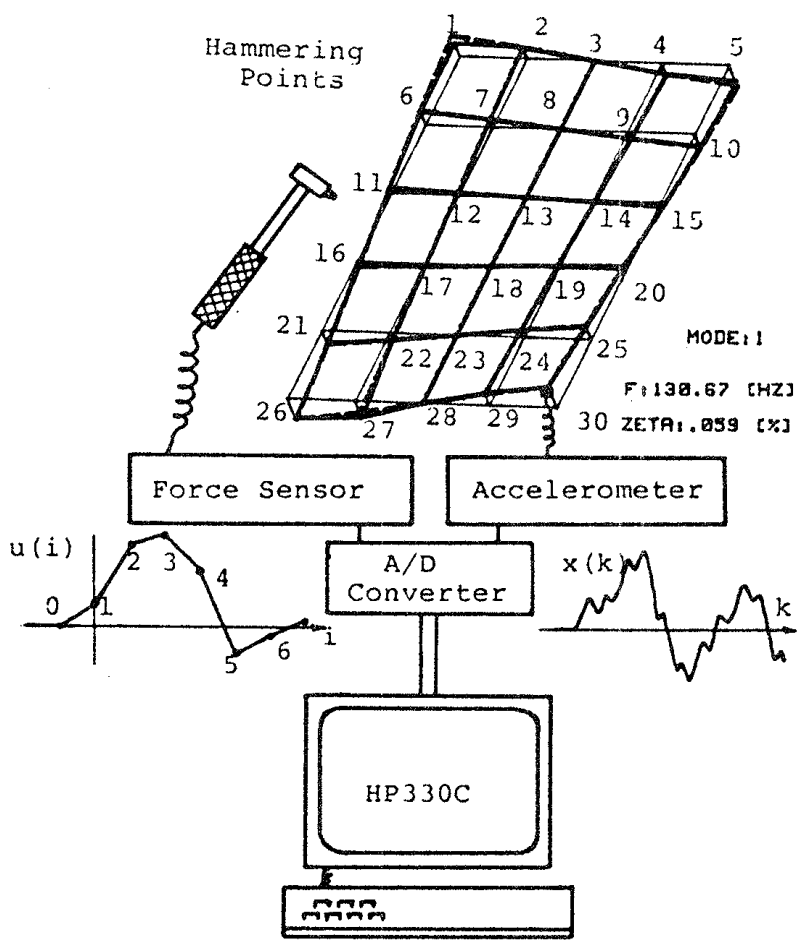

図 1 実験モード解析系の瞔成
きれた，搆造物の自由振動方程式は、次のマトリック ス方程式で与えられる。

$$
\boldsymbol{m} \ddot{x}+c \dot{x}+k x=0
$$

あるい流 $v=\dot{x}$ 使うと，次の状態方程式となる。

$$
\left.\begin{array}{l}
\dot{x}=v \\
\dot{v}=-m^{-1} c v-m^{-1} k x
\end{array}\right\}
$$

式(1)，（2）の係数を同定すると言う点加考えると, 式中の $x, v$ 社変位と速度である必要はない。これら の式を微分あるい性積分しても成立する。したがって 速度と加速度，あるいは変位の積分と変位といった組 合せでも成立する。一般の実験モード解析が，加速度 センサで構築される方式にも，これからの議論は当て はまる。

式(1)あるいは式(2)を，時刻 $t=i T$ で離散化す ると, 次の線形離散モデルとなる。

$$
\boldsymbol{x}(i)=\boldsymbol{A} \boldsymbol{x}(i-1)+\boldsymbol{B} \boldsymbol{x}(i-2)
$$

あるいは $2 n \times 2 n$ のマトリックス $D$ を使って

$$
\boldsymbol{y}(i)=\boldsymbol{D} \boldsymbol{y}(i-1)
$$

と表される。状態量 $\boldsymbol{y}=\left[\boldsymbol{x}^{T} \boldsymbol{v}^{T}\right]^{\top}$ を使えば，式（4)の $2 n \times 2 n$ マトリックスを同定することとなる。しかし この場合は，2 種類のセンサを必要とする。本論文で は式（3)の $n \times n$ マトリックス $\boldsymbol{A}, \boldsymbol{B}$ を同定する。

$2 \cdot 2$ インパルス応答の抽出式 $(3)$ は, 激散化 された多自由度の減衰自由振動方程式である。これよ り $A, B$ を推定するためには，減衰振動の多点同時計 測を行い，すべての点の応答 $\boldsymbol{x}(i)$ を必要とする。著者 らに洨点同時計測は不可能なため，前報で開発した インパルス応答の抽出とその平均化によって代替す る $^{(9)}$. ハンマリング試験ての加振力を $u(i)$, 応答を $x(k)$ とすると, ハンマリング力は完全なインパルス ではない.しかもその大きさによって，応答の大きさ も変化する。これを以下のような方法で, 基準化する。 離散系の入出力関係はインパルス応答 $g(k-i)$ を使 って次のように表せる。

$$
x(k)=\sum_{i=0}^{k} g(k-i) u(i)
$$

ハンマリングの同期点を $x(1), u(1)$ とし, $(2-L) よ り$ L点までのデータで次のマトリックス式を作る.

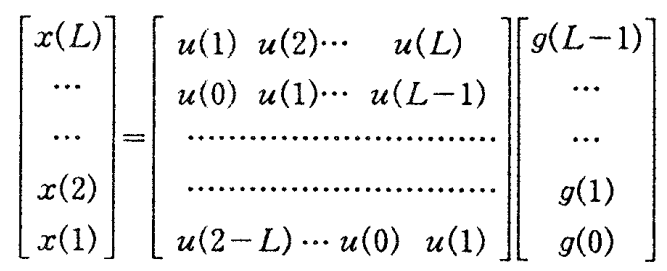

式 (6)をガウスの消去法で解き，インパルス応答 $g(i)$ が求められる。これを平均化して, 信頼性を高めるこ 
とができる， $j$ 回め $(j=1,2, \cdots, K)$ の試験ごとに求ま ったインパルス応答を $g^{(j)}(i)$ とすれ淁, 平均化したイ ンパルス応答とその分散は，次式で求められる。

$$
\begin{aligned}
& g(i)=\frac{1}{K} \sum_{j=1}^{K} g^{(j)}(i) \\
& \xi_{i}^{2}=\frac{1}{K-1} \sum_{j=1}^{K}\left[g^{(j)}(i)-g(i)\right]^{2}
\end{aligned}
$$

これを測定すべき $n$ 点について，ハンマリング点 $l$ を 変え $(l=1,2 \cdots n), g_{l}(i)$ を求める.

$2 \cdot 3$ 係数 $A, B$ 同定 ハンマリング点 $l=1$ か ら $n$ まで, $g_{l}(i)$ を綐に配列して次のインパルス応答 ベクトル $\boldsymbol{g}(i)$ を定義する。

$$
\boldsymbol{g}(i)=\left[g_{1}(i) g_{2}(i) \cdots g_{n}(i)\right]^{T}
$$

この $\boldsymbol{g}(i)$ を式(3)の $x(i)$ に代入し，転置すると次の 関係を得る。

$$
\boldsymbol{g}(i)^{T}=\left[\boldsymbol{g}(i-1)^{T} \boldsymbol{g}(i-2)^{T}\right]\left[\begin{array}{l}
\boldsymbol{A}^{T} \\
\boldsymbol{B}^{T}
\end{array}\right]+\boldsymbol{e}^{T} \cdots \cdots(9)
$$

ここで $\boldsymbol{e} は$, 式(3)の方程式愦差となっており, 測定 愦差や高次振動成分を吸収しようとする項である.

式(9)を， $i=3$ から $I$ まで緃にならへてて, 次のマト リックス形式に表す。

$$
E=G-G^{*} X
$$

$$
\Xi こ て
$$$$
G=\left[\begin{array}{c}
g_{1}(3) \cdots g_{n}(3) \\
g_{1}(4) \cdots g_{n}(4) \\
\cdots \cdots \cdots \cdots \cdots \\
\cdots \cdots \cdots \cdots \cdots \\
g_{1}(I) \cdots g_{n}(I)
\end{array}\right]
$$

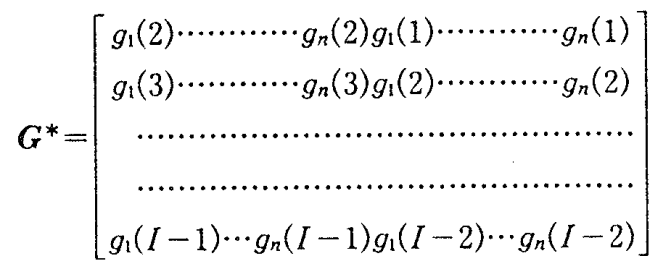

$$
X=\left[\begin{array}{l}
A^{T} \\
B^{T}
\end{array}\right]
$$

末知ベクトル $X$ の大きさは $2 n \times n$ 大あり，式(10)の 方程式の数は $(I-2) \times n$ である。したがってデー夕点 数を, $I \geqq 2 n+2$ と選べば, 最小二乗法で解くことがで きる、愦差の二乗和 $\lambda$ を重みWをはさんで次のよう に定義する。

$$
\lambda=\operatorname{trace} \boldsymbol{E}^{r} \boldsymbol{W E}
$$

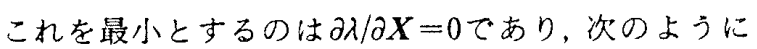
未知係数を求めることができる。

$$
\boldsymbol{X}=\left(G^{* r} \boldsymbol{W} G^{*}\right)^{-1} G^{* r} \boldsymbol{W} \boldsymbol{G}
$$

$2 \cdot 4$ 固有振動数と振動モードの決定 式(3)の運
動方程式が同定できれば，状態量 $\boldsymbol{y}=\left[x^{T}(i) x^{T}(i\right.$ -1) $]^{T}$ を使って

$$
\begin{gathered}
\boldsymbol{y}(i)=\left[\begin{array}{l}
\boldsymbol{x}(i) \\
\boldsymbol{x}(i-1)
\end{array}\right]=\left[\begin{array}{ll}
\boldsymbol{A} & \boldsymbol{B} \\
\boldsymbol{I} & \boldsymbol{O}
\end{array}\right]\left[\begin{array}{l}
\boldsymbol{x}(i-1) \\
\boldsymbol{x}(i-2)
\end{array}\right] \\
=D_{\boldsymbol{y}}(i-1)
\end{gathered}
$$

と置き換え，踓散正準方程式を作成する。ここではは 単位マトリックス，0証零マトリックスである。これ を,

$$
(z I-D) \boldsymbol{y}=\mathbf{0}
$$

の形の固有値解析を行うことで， $z$ 領域の固有値 $z_{i}$ と, 対応する固有べクトル $\boldsymbol{y}_{i}$ 救めることができる.この 根 $z_{i}$ の中で, 振動的で低次の根を選び

$$
\begin{aligned}
& s_{i} T=\ln z_{i}, z_{i}=\exp s_{i} T \\
& s_{i}=\sigma_{i}+j \omega_{i}, \omega_{n i}=\sqrt{\sigma_{i}^{2}+\omega_{i}^{2}}, \quad \zeta_{i}=\tan ^{-1} \sigma_{i} / \omega_{i}
\end{aligned}
$$

の変換によって, 固有振動数 $\omega_{n i}$ と減衰率 $\zeta_{i}$ を得る. 振動モードは, 式(14)で求められた固有べクトル

$$
\boldsymbol{y}_{i}=\left[\begin{array}{lll}
x_{i}^{T} & z_{i} x_{i}^{T}
\end{array}\right]^{T}
$$

のうち，上半部を取れば $i$ 次の固有モード $x_{i}$ が求め られる.この固有モードの $k$ 点の要素 $x_{i}(k)$ の実数部 $x_{\mathrm{R} i}(k)$ と虚数部 $x_{\mathrm{I} i}(k)$ より, 振幅と位相は

$$
\begin{aligned}
& A_{i}(k)=\sqrt{x_{R i}^{2}(k)+x_{i i}^{2}(k)} \\
& \phi_{i}(k)=\tan ^{-1}\left\{x_{1 i}(k) / x_{R i}(k)\right\}
\end{aligned}
$$

と求められる。これを複素面内で描く平面べクルの, 主軸への投影で実モード近似することができる。

\section{3. 実験結果と考繁}

前述の実験モード解析手法の有効性を確かめるた め，2 種類の実験を行う。これらは前報と比較するた $\bigotimes^{(9)}$, 同じ係数を持つ 5 自由度のシミュレーションと， 宙吊り平板の実験を取り上げる。

$3 \cdot 15$ 自由度集中定数系のシミュレーション 図 2 に示す 5 自由度系をアナログ計算機にシミュレー トし, 前節の手法を適用する. 外力は発振器より擬似 インパルス入力を加え，その応答を取り込む。ここで は $m_{2}$ に力を加え, 変位応答 $x_{1} \sim x_{5}$ を 2 チャンネル $\mathrm{A} / \mathrm{D}$ コンバータでコンピュータに取り込さ. 加振力と 芯答から, 式(6)でイパルス応答を抽出し, 式 (7) で5回平均化し，これを式(12)に代入して $\boldsymbol{A}, \boldsymbol{B}$ マト リックスを同定する。な㧊測定条件は各点で同じであ り, 式（7）のデータの分散は等しかったので, 重み $W$ は省略した。これより式(13)の $\boldsymbol{D}$ マトリックス $(n=5$ であるから $10 \times 10$ マトリックス)を作成し， 2 段 QR 法で固有值解析を行う，同定された固有值を，式(15) で固有振動数と減衰率(\%)に淔し図 3 の右に，また式 
（16）（17)で求めたモードを図中の実験で示す。精度確 認のため, シミュレーション設定值より求奻た固有振 動数と，減衰梁（\%）を同図左に，モードを点線で示 す。割合に良い一致をみている。しかし 27 次の離散フ イルタで同定し，十分に剩余項を考虑した前報の結果 よりは誤差が增えている。これは本手法が、各質点に 1 自由度を与えて 5 自由度モデル(10次)で同定して おり，いわゆる剩余項を考慮できないためである。ア ナログ計算機のシミュレーションは，実験よりは条件 は良いとは言え,シミュレーション䛊差や A/D コン バータの変換誤差などが入る，集中定数系に本方式を 適用する場合，剩余項を入れる妥当で簡便な方法はな い.しかし実際の構造物の場合，測定点数は同定した いモード数の数倍で、この差が剩余項となるため，実 用上の障害とはならないと考えられる。

次に点 3 の測定データ $g_{3}(i)$ を1.5倍して同定を試み る、実験モード解析では, 測定面を直角にハンマリン グできなかったり, 加速度センサの感度が少し変化し てしまうことは良く起こる。本手法は空間フィル夕的

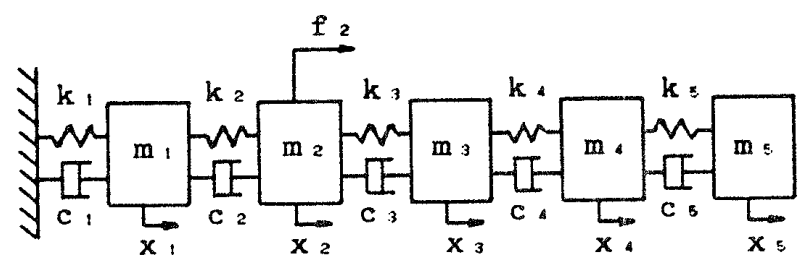

$w_{i}=0.25[\mathrm{~kg}], \mathrm{k}_{i}=5 \times 10^{4}[\mathrm{H} / \mathrm{s}], \mathrm{C}_{1}=5[\mathrm{Hs} / \mathrm{a}]$

$$
(j=1,2 \cdot \ldots 5)
$$

図25 自由度集中筫量モデル

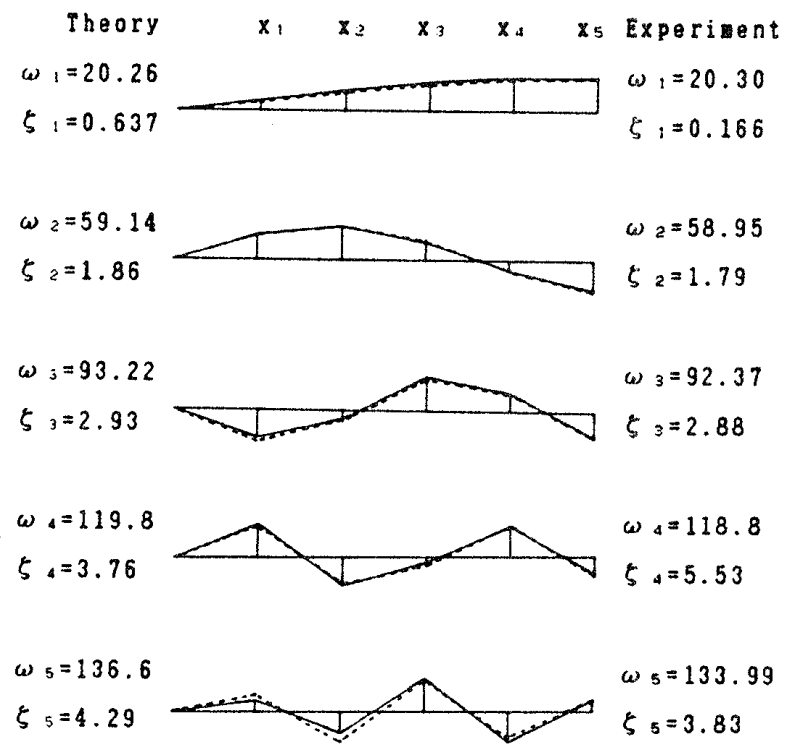

図 3 同定されたモードと計算されたモードの比較 (同定条件： $T=1.95 \mathrm{~ms} ; n=5, I=100$ )
特性を使っているのて，低次モードに対し測定倍率の 誤荎に対寸る精度向上が期待できる。解析結果から求 められたもードを，図4に示す。当初期待したような， 低次モードに対して空間フィル夕的効果は残念ながら なく，点 3 の振幅が大きく現れている．逆に考えれば， 測定が解析結果に良く反映されている。したがって， 本方式でも従来方式同様に，測定感度などには十分に 注意しなければならない。なお，図40右側に示すよ うに，固有振動数と減衰率は図 3 の場合と全く同一で ある。

$3 \cdot 2$ 宙吊り平板の実験前述の実験では入れら

表 1 同定された特性根の比較

\begin{tabular}{|c|c|c|c|c|c|c|}
\hline $\mathrm{N}$ & 0. & & (6), $[\mathrm{Hz}]$ & $\zeta,[\%]$ & prev. (s) & $F \cdot E \cdot M \cdot(s)$ \\
\hline$?$ & 1 & $y$ & 100.3040 & 90.283 & & \\
\hline t & 71 & ) & 116.6249 & 96.493 & & \\
\hline 1 & $\because$ & ? & $122.420 \%$ & 95.522 & & \\
\hline ! & 4 & $i$ & 130.6777 & .05927 & 130.65 & 133.3 \\
\hline 1 & 51 & ) & 163.9410 & 37.667 & & \\
\hline 1 & $A$, & ; & 147.2900 & 52.37 & & \\
\hline 1 & 73 & ) & 178.7077 & .05150 & 173.79 & 172.7 \\
\hline 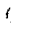 & $\theta ;$ & j & 123.5720 & 55.785 & & \\
\hline 1 & $7)$ & ) & 224.7905 & 47.747 & & \\
\hline 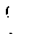 & 10 & ? & 25! . 2ha & 79.797 & & \\
\hline 8 & 11 & \} & 247.720 & $24.47 ?$ & & \\
\hline 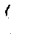 & 12 & ? & 269.017 & 50.811 & & \\
\hline 1 & 13 & $i$ & 270.560 & .01714 & 270.43 & 263.2 \\
\hline$r$ & 14 & ) & $x n y_{n} 44 n$ & 12.212 & & \\
\hline$t$ & 15 & ; & 314.763 & 41.974 & & \\
\hline ! & 16 & ) & 300.976 & .02500 & 321.02 & 321.6 \\
\hline$t$ & 17 & ) & 320.410 & 48.63 & & \\
\hline ( & 18 & ) & 35,145 & 17.9 & & \\
\hline 1 & 17 & ' & 347.345 & .14451 & 367.55 & 363.6 \\
\hline$?$ & 20 & ! & $450.26 \%$ & 97.5 .27 & & \\
\hline 1 & 21 & ; & 502.462 & 10.100 & & \\
\hline$\ell$ & 2 & ; & 508.405 & .04014 & & \\
\hline c & 27 & ) & $538.38 \%$ & $7.350 ?$ & & \\
\hline 1 & 24 & 1 & 628.989 & .18503 & & \\
\hline$r$ & 25 & $y$ & 6.5 .909 & 4.1292 & & \\
\hline
\end{tabular}

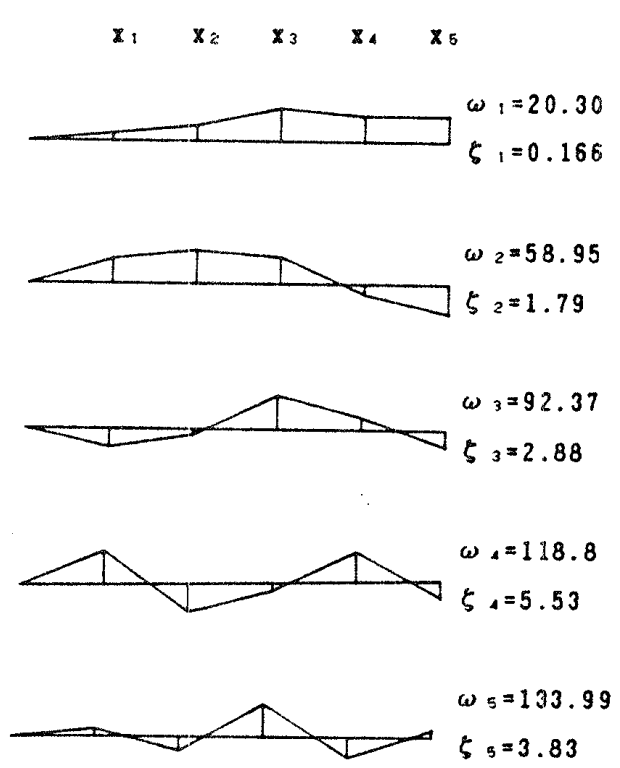

図 4 測定感度のモードと固有振動数への影非 


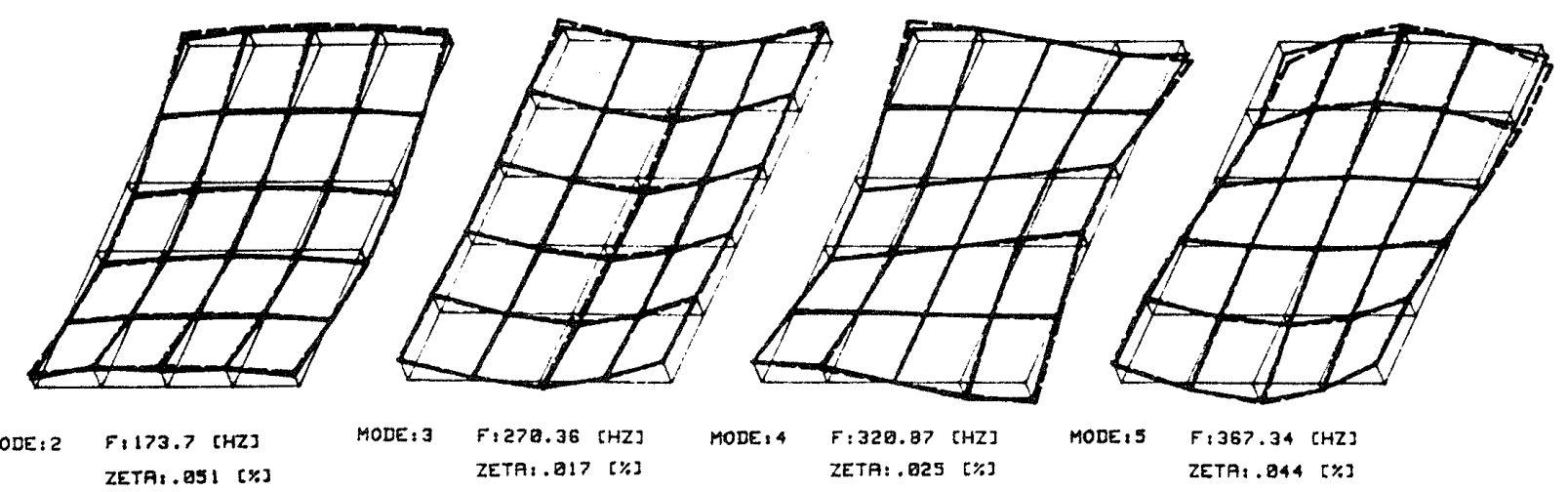

図 5 同定された鋼板の振動も一ト（同定条件 $T=0.78 \mathrm{~ms}, n=30, I=250$ )

れなかった剰余項が考慮でき，実際にハンマリングカ を加える連続体のモード解析として, 図 1 に示す宙吊 り平板を取り上げる．厚さ $4.5 \mathrm{~mm}$ ，大きさ $300 \times 360$ $\mathrm{mm}$ の鋼板をゴムで宙吊りとし，図１に示された点 30 に加速度計を取付け, 点 1 より順にハンマリングを 繰返す。この加速度応答波形に, 前述の手法を適用す る.計算条件は $T=0.78 \mathrm{~ms}, n=30, I=250$ であり， 8 回の平均でインパルス応答を抽出し、マトリックス $\boldsymbol{A}, \boldsymbol{B}$ を同定する。これより式(13)のマトリックス $D$ (大きさ $60 \times 60)$ を作成し，固有值解析を行う。求め られた固有振動数 $[\mathrm{Hz}]$ と減衰率 $[\%]$ を, 表 1 に示 す. 25 個の共役な振動根が求められている.残り 10 個 はすべて，安定な実根である.本方式は，測定点を1自 由度としてモデル化しており，応答が安定であれば基 本的には不安定な根は同定されない。これは AR 法や Prony 法では，次数の決定や不安定根の問題があるの に対し ${ }^{(8)(6)}$, 本方式の傮位性を示している。共振根の中 でも，測定周波数 $500 \mathrm{~Hz}$ 以内の共振根 5 個はすべて 減衰が小さく，それ以外の根は，急速に減衰する根で ある。測定をゃり直しても，この傾向は変らず，䉍単に

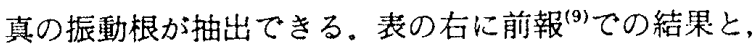
有限要素法 (NASTRAN) の計算結果を, 比較のため に示す.FEM では減衰の值は求められないが，5個の 弾性モードの共振周波数はよく一致している。かずか な違いは測定誤差と言うよりは，FEM 解析での板厚 などが少し䧺ったためと思われる。

モード形の比較を図 1 (モード1) と図 5 (モード 2 から5）に示す。練い実線は変形前の形状で，太い実線 が同定されたモード形, 点線が FEMで求まったモー ド形である，加速度計を取付けた影響や，端の点での ハンマリングの誤差によって少し暹いが現れるが，比 較的良い精度のモード形を示している。この計算時間 は HP330C BASICで 15 min であり，計算効率も覀 くない.

\section{4. 結論}

ハンマリング応答の測定点に 1 自由度 ( 2 次)の離散 モデルを当てはめ, 多変数の離散方程式を同定し, そ の特性マトリックスを固有值解析するモード解析法を 提案した。これをシミュレーションと実際のハンマリ ング実験に適用し，次の結論を得た。

（1）本方式では測定点に1自由度を与え，測定点 数の自由度で離散モデル化するので，応答が安定であ れば基本的に安定な根が求まり，真の根の抽出が容易 であり，固有値の同定精度も良い。

（2）モード形は測定データをよく反映しており, その精度は従来の方式とほ济同じと考えられる。した がって, 検出器の精度などには，十分注意しなければ ならない。

（3）次数は測定点数によって決定されるため, 極 めて合理的に次数决定がなされる，反面，集中定数系 に対しては，剩余項を考慮できない。

\section{文献}

（1）大久保，機械のモーダルアナリシス，(1981）４7，中央大学 出版全。

（2）長松，モード解析，(1985)，99，培風館

（3）日本機械学会編，モード解析の基䂣と充用，(1986)，38 丸 语.

(4) Brown, D. L., ほか 3 名, Parameter Estimation Techniques foe Modal Analysis, SAE paper, No.790221. (1979).

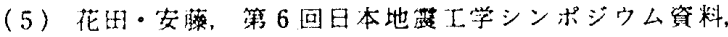
(1981), 905.

(6) Mergeay M., Multi Degree of Freedom Parameter Estimation Methods for Modal Analysis, Annals of the CIRP. 31 (1982), 269.

(7) Ibrahim. S. R. and Mikulcik, E. C.. The Shock and Vibration Bulletin, 47-4(1977), 183.

（8）鈴木・河野边, 機論, 53-496, C (1987), 2445.

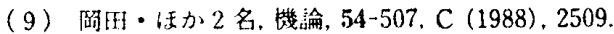

(10) Schmerr, L. W.. A New Complex Exponential Fre. quency Domain Technique for Analyzing Dynamic 
Response Data. Proc. of the Ist Int. Wodal Analysis Conf., (1982), 183.

(11) Coppolino, R. N., A Simultaneous Frequincy Domain Technique for Estimating Mrdal Parameters from Measured Data. SAE paper, No.811046 (1981).

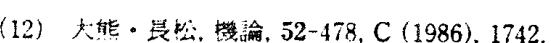

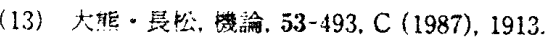

(14) Leuridan, J. M., 添か, 2 名. Direct Parameter Identification of Mechanical Structures with Application to Modal Analysis, AIAA 82-0767-CP. (1982), 497.

\section{討 論}

〔筫問〕鈴木浩平・吉村卓也 (東京都立大学工学部)

（1）著者らの提案されている多変数離散モデルを 用いたモード特性の同定法は，多点参照の曲線適合方 法である時間領域データを用いたボルドの方法(2)（ポ リリファレンス）において，同定自由度を测定点数に 等しく扔いて解く場合と一致する。

したがって，提案された方法はボルドの方法の特別 な場合とみなすことができまた，ボルドの方法では 同定自由度を測定点数に必ずしも一致させる必要はな いことから，後者のほうが同定法としては僈れている のではないかと考えられるがいかがか。

（2）上で述べたのと同様な理由により，式(14)の 固有值解析によって得られた固有值から真の根を選択 するのは，時間領域の一般の曲線適合と同様，必ずし も容易ではないのではないかと思われる，同定自由度 が測定点数に等しいとき，真の根の抽出が容易である と考える根拠は何か。

（3）著者の述べられている空間フィル夕とは何 か.

〔回答〕（1）ボルドの方法との大きな違いは， 多チャネルのデータ収集システムが不要で, FFT 演 算誤差などが擗けられることである。したがって一点 加振, 一点応答測定を繰返し, 精度良いモード解析が できるうに工夫している。

もう一点は，質問者かご指摘のように，同定自由度 と測定自由度を一致させ，有限要素と同じようなモデ
ル化をしたことである。これは質問 $(2)$ と関連するの で，以下のように回答させていただく。

（2）同定されるべき根の数は, 普通数〜十数個で あり，それ以上の共振牥エリアジング防止フィル夕 で測定されない。一方測定自由度は，モード形を作る ためこれょり多いことが一般的である。この差が剩余 自由度となり，誤差を吸収する。剩余自由度は同定根 の精度向上には役立つが, 反面偽の根が入り真の根の 選択を困難汇する。本手法は同定自由度を測定自由度 と一致させることで, 同定モデルを有限要素モデルに 選んでいる。そのた测定した波形が安定な波形であ れば，不安定根や偽の共振根が混入しずらく，剩余自 由度で同定される根はノイズなどによる隇衰の良い根 か,アンチエイリアジングなどの高次の根である。一 般の時間領域同定法に比べて本手法は低次の共振根を 選択することで，真の根を容易に分離することができ， 優れていると考えるわけである。

（3）例えば時間領域の離散方程式同定 (AR 法)で あれば，同定された特性根の波形が抽出され，時間フ イル夕の役割をしてくれるわけである。本手法は空間 的にも離散方程式を使っているので，特性根に対応し た振動モードが,データの胁がみを訂正するような形 で同定してくれないか，と期待したわけである。この 空間的なモード形のフィル夕特性があれば，同定上は きわめて有利と考えられるが、残念ながらこの性質は なかった。 